\title{
Sciendo
}

Administration, vol. 68, no. 1 (2020), pp. 1-13

doi: 10.2478/admin-2020-0001

\section{Political developments, 2019}

\author{
David Hugh Moore \\ Department of Political Science, Trinity College Dublin, Ireland
}

\section{European Parliament election}

On 24 May 2019 Ireland voted in the ninth European Parliament elections. As a result of Brexit, the European Parliament was reorganised and the number of MEPs was reduced from 751 to 705 . The twenty-seven remaining UK seats were reallocated to other member states. Ireland received an additional two seats, bringing the country's total number of seats up to thirteen. The same constituencies as in 2014 were used with only minor border changes. Two constituencies received an additional MEP. Dublin moved from a three-seat to a four-seat constituency while Ireland South went from a four- to a five-seat constituency. The Midlands North-West constituency stayed the same with four seats. Given that the UK had not actually left the EU when the elections were held, the two additional MEPs were ineligible to take their seats until the UK had officially left the EU.

In order to be eligible to compete in European elections, a prospective candidate must fulfil one of the following criteria: be nominated by a registered political party; have declarations from sixty people willing to support their candidacy; or pay a deposit of $€ 1,800$. These requirements are deemed relatively simple to meet and as such helped contribute towards a record number of candidates running for MEP in the state. In total, fifty-nine candidates ran for election: nineteen were located in Dublin, twenty-three in Ireland South, and seventeen in Midlands North-West. Of the eleven incumbent MEPs, 
seven sought re-election. Fine Gael's Brian Hayes, Fianna Fáil's Brian Crowley, and independents Marian Harkin and Nessa Childers did not seek re-election.

Most of the party candidates were either sitting or former MEPs, TDs or local county councillors. Fine Gael ran former Rose of Tralee Maria Walsh in Midlands North-West, former leader of Northern Ireland's Social Democratic and Labour Party Mark Durkan in Dublin, and former Tánaiste Frances Fitzgerald also in Dublin. In addition to the party candidates, there were a sizeable number of independents. High-profile independents included Independents 4 Change TDs Mick Wallace and Clare Daly, incumbent MEP Luke 'Ming' Flanagan, former presidential election candidate Peter Casey and Senator Alice-Mary Higgins, daughter of President Michael D. Higgins (see Duggan, 2019).

Fine Gael won five seats, with 29.6 per cent of the vote. This was followed by Fianna Fáil (16.5 per cent), the Green Party (11.7 per cent) and Independents 4 Change (7.4 per cent), who all won two seats. Labour (3.1 per cent), Solidarity/People Before Profit (2.3 per cent) and the Social Democrats (1.2 per cent) all failed to win seats. A total of 16.8 per cent of the electorate voted for independent candidates, with a return of one seat in the form of Luke 'Ming' Flanagan (see Johnson, forthcoming).

\section{Local elections}

On the same day as the European Parliament elections, the local elections were held. These elections marked the 120th anniversary of Ireland's first local elections in 1899, following the passing of the Local Government (Ireland) Act, 1898. Many local authorities celebrated the anniversary, with the Minister for Local Government and Electoral Reform, John Paul Phelan, TD, launching a departmentfunded visual exhibition of the history of Irish local government in the Customs House. The year 2019 also represented the twentieth anniversary of the constitutional amendment passed in 1999 to safeguard the holding of local elections on a five-year basis.

Elections took place for three city councils, two city and county councils, and twenty-six county councils. There were also local plebiscites in Cork City, Limerick and Waterford on the introduction of a directly elected mayor. The elections failed to rouse much public interest, with a turnout of just 50.2 per cent, the joint lowest in the state's history. As is usual in local elections, the election was fought on 
a mixture of local and national issues. Fianna Fáil maintained its position as the largest party in Irish local government with 26.9 per cent of first-preference votes translating into 279 seats. This represented an increase of 12 seats. Having lost 105 seats in the 2014 local elections, Fine Gael were hoping for a strong showing. However, they only gained 20 seats, increasing their total from 235 to 255. Nonetheless, they had reversed the pattern of parties losing seats while in government. Sinn Féin had been the big winners in the 2014 election with 159 seats, notably controlling Dublin City Council. However, they lost 78 seats, with their total falling to 81. The Labour Party increased its share of seats by 6 , from 51 to 57 . The Green Party were perhaps the story of the election, increasing their number of seats fourfold from 12 to 49 . Independent candidates, who generally do better in local elections, received 22.4 per cent of the vote, translating into 198 seats. The Social Democrats and Solidarity/People Before Profit won 19 and 11 seats, respectively.

Campaigning for the plebiscites was lacklustre, characterised by a dearth of information and public confusion. The proposal was narrowly defeated in Cork City and Waterford; conversely, it passed in Limerick, where a mayoral election is expected to take place in 2021 (see Quinlivan, forthcoming).

\section{Divorce Referendum}

On 6 July 2016 Fine Gael TD Josepha Madigan introduced a private members' bill that proposed halving the length of time that couples had to wait prior to seeking a divorce. In April 2017 the government agreed to adopt the proposal and it was sent to the Oireachtas Select Committee on Justice and Equality.

While the bill had received government support, it was one of several referendums intended to liberalise Ireland's Constitution that the government wished to bring to the people. Further, it was deemed to be a low-priority referendum, especially with the government's desire to hold a referendum on the repeal of the Eight Amendment to the Constitution, regarding abortion (see Moore, 2019). In January 2019 the Cabinet approved the holding of a referendum to amend Articles 41.3.2 and 41.3.3 of the Constitution. The date for the referendum was set for 24 May to coincide with the local and European Parliament elections.

On 26 March the formal wording of the referendum was announced. The referendum would allow for the recognition of 
foreign divorces and would eliminate any language relating to a minimum separation term for divorcing couples. The government also published a draft bill to replace existing legislation should the referendum pass. The bill would impose a two-year mandatory separation period (a reduction from four years). In April the final version of the bill on the Thirty-Eight Amendment to the Constitution passed both the Dáil and the Seanad.

The referendum was ultimately passed by a majority of 82.1 per cent in favour to 17.9 per cent against, with 2.3 per cent spoiled/invalid votes. While there was variation across urban and rural regions the amendment was overwhelmingly approved across the state. The highest 'No' vote was in Monaghan, where just under 25 per cent of voters opposed the amendment (see Keenan, forthcoming).

In October the Family Law Act, 2019, which would recognise foreign divorces and reduce the separation period for divorcing couples, passed both houses of the Oireachtas and was signed into law by President Michael D. Higgins. This bill also included a provision to recognise UK divorces in the event of a no-deal Brexit.

\section{By-elections}

One implication of the European Parliament elections was that four of the newly elected MEPs were, at the time of the election, TDs. These were Fine Gael TD and former Tánaiste Frances Fitzgerald of the Dublin Mid-West constituency, Fianna Fáil TD Billy Kelleher of the Cork North-Central constituency, and independents Clare Daly and Mick Wallace from the Dublin Fingal and Wexford constituencies, respectively. Under the Electoral (Amendment) Act, 2011, the writ for such by-elections must be issued within six months of the vacancy. On 7 November 2019, the Minister for Housing, Planning and Local Government, Eoghan Murphy, TD, brought the writ before the Dáil for by-elections to be held in the four constituencies on 29 November (see McGee, 2019).

On the week of the writ going before the Dáil, thirty-two candidates had already declared their intentions to compete in the elections. This figure would rise to forty-six by the 18 November deadline for candidate nominations. Going into the election, Fianna Fáil were the slight favourite in three of the four constituencies.

In the build-up to polling day, Verona Murphy, Fine Gael's candidate in the Wexford constituency, aroused controversy following comments relating to asylum seekers. While discussing the direct 
provision system, Murphy, the former leader of the Road Haulage Association, was quoted as having said:

These people are coming from such war-torn countries that they have to be deprogrammed, for the want of a better word, but through support services. They carry angst that you wouldn't ordinarily see, possibly infiltrated by ISIS and we have to protect ourselves against that.

Over the following few days, Murphy made similar comments in two more interviews. These comments immediately received criticism across the political spectrum, including within her own party, with Murphy herself having to publicly apologise (see Kelly, 2019b). Following the suspension of plans to have a direct provision centre in Oughterard, Co Galway, due to local objections, and in Rooskey, Co Leitrim, following several suspected arson attacks on a hotel that was to be used as a direct provision centre, many felt that Murphy's comments represented a growing anti-asylum-seeker sentiment in Ireland (see Pollak, 2019a, 2019b). Further, some also viewed this as additional evidence of discriminatory sentiment entering Irish political discourse following Peter Casey's anti-Traveller comments and subsequent second-place finish in the 2018 presidential election (see Duggan, 2019; Leahy, 2019).

Aside from the controversy surrounding Verona Murphy, the byelections did not arouse much interest from the public. One reason for the low turnout was the public's anticipation of a general election in the new year. Thus, there was apathy towards the by-elections as they were seen as having no real impact with fresh elections expected so soon. Turnout across the four constituencies was 29.42 per cent, with a high of 35.26 per cent in Wexford and a low of 25.59 per cent in Dublin Fingal. For perspective, the turnouts in the 2011 and 2016 general elections were 70.1 per cent and 65.2 per cent, respectively. Fianna Fáil won seats in Cork North-Central and Wexford while Sinn Féin and the Greens won a seat in Dublin Mid-West and Dublin Fingal, respectively (see 'Live results', 2019).

\section{Northern Ireland}

Since the Northern Ireland Assembly elections in May 2016 the major political parties have not been able to come to an agreement on a legislative programme and have prevented the restoration of the 
country's power-sharing executive. The main sticking points between the Democratic Unionist Party (DUP) and Sinn Féin have been the Irish Language Act (an important issue for Sinn Féin) and the sustainability of any reforms to Stormont (see O'Donnell, 2017). In late December, in negotiations facilitated by Tánaiste Simon Coveney, TD, and the Secretary of State for Northern Ireland, Julian Smith, $\mathrm{MP}$, an agreement was reached by four of the five main parties in Northern Ireland, with the DUP refusing to sign off on the agreement (see Emerson, 2019). Following the failure of the DUP to sign the agreement, Smith set a deadline of 13 January 2020. If no agreement has been reached by this date Smith will call a new Assembly election (see Leahy et al., 2019).

In the UK general election the DUP lost one seat, Sinn Féin neither lost nor gained a seat, and the Social and Democratic Labour Party and the Alliance Party of Northern Ireland (Alliance) gained two and one seats, respectively. This meant that for the first time there were more Republicans than Unionists elected to Westminster in Northern Ireland, as Alliance is neutral on the idea of a unified Ireland (see 'Election results', 2019).

\section{The National Children's Hospital}

In late 2018 it emerged that the new National Children's Hospital was expected to cost significantly more than was initially budgeted. This was another source of criticism towards the government over the project, with politicians from opposing parties regularly stating that the hospital should have been built at Connolly Hospital in Blanchardstown rather than at St James's Hospital, Dublin. In early 2019 it emerged that the construction of the hospital was expected to cost $€ 1.433$ billion, $€ 450$ million higher than the initially approved budget of $€ 983$ million. When other costs are added, the project is expected to cost $€ 1.73$ billion, with the potential for this figure to rise even further. In response to the cost overruns, the Health Service Executive appointed PwC to carry out a review of the situation. The report was published in April and included strong criticism of the contracting and governance arrangements. These new projections called into question the viability of other capital projects and plans for healthcare in Ireland, as funding for these would have to be moved to bridge the gap between budgeted and actual costs for the hospital. Given the significant pressure on the government to enhance the overall provision of healthcare in Ireland, in line with the Sláintecare 
action plan, such increased cost for the building of the National Children's Hospital may have significant repercussions on healthcare provision in the state going forward (see McConnell, 2019).

\section{Maria Bailey}

In the week preceding the May local elections, Fine Gael TD Maria Bailey attracted controversy after it emerged she was involved in a lawsuit against the Dean Hotel in Dublin. Bailey claimed that she had injured herself after falling from an indoor swing in the hotel, stating that no instructions on how to use the swing were provided. However, the hotel maintained that Bailey had been holding items in both hands at the time of the fall. This incident was particularly controversial as, at the time, there was a specific political focus on personal injury awards and high insurance costs. Bailey dropped the compensation claim after it emerged that she had run a ten-kilometre race three weeks after the fall. This was considerably damaging for Ms Bailey as in court filings she had claimed she still could not run three months after the accident. Photos also emerged of Bailey attending the Longitude Musical Festival eight days after the incident.

On 27 May Bailey gave an interview on the Today with Seán O'Rourke RTÉ radio programme. During the interview Bailey claimed that the media had 'crossed the line of public invasion and humanity'. The interview was described by senior members of Fine Gael as a 'car crash' and the 'worst political interview I have ever heard', with Minister for Health Simon Harris, TD, and Taoiseach Leo Varadkar, TD, both stating that the interview was unwise. The interview increased the level of pressure that Ms Bailey was facing within the party, with Fine Gael launching an internal review. As a result of this review, Bailey was removed from her post as chair of the Oireachtas Housing Committee. Further, in October, Bailey faced a vote of no confidence from her constituents and in November the Fine Gael National Executive voted to deselect her as a candidate in the next general election. The incident was seen to have damaged the reputation of Fine Gael, especially in the build-up to the May local elections (see Kelly, 2019a).

\section{Lyra McKee}

On 18 April, amidst rising tensions in Northern Ireland, journalist Lyra McKee was shot dead in Derry. Riots had broken out due to the 
seizure of munitions by the Police Service of Northern Ireland in the build-up to the commemorations of the 1916 Easter Rising. Police say that up to twelve shots had been fired at officers during the riots and McKee was standing near an armoured police vehicle when she was shot in the head. She was transported to Altnagelvin Area Hospital, where she was later pronounced dead. The New IRA later admitted responsibility for her death, stating that McKee had not been the object of the attack and apologising to her family and partner. The killing was the first time a journalist had been killed in the UK since the assassination of Martin O'Hagan in 2001 and contributed towards fears that violence would return to Northern Ireland in the wake of Brexit (see McClements, 2019).

\section{Irish Nurses and Midwives Organisation's Industrial Action}

In late 2018 the Irish Nurses and Midwives Organisation (INMO) voted to take industrial action following a dispute with the government over pay and conditions, with the INMO claiming that existing standards had led to a recruitment and retention crisis. The strikes took place in late January and early February 2019 and had broad support from the public. However, Fine Gael did not want to give into demands as they feared it would encourage other public service groups to seek improved pay and conditions. On 2 May, following months of negotiations involving the INMO, SIPTU, public services management and the Labour Court, INMO members voted 62 per cent in favour to accept a new offer put forward by the government, ending the potential of further strikes (see Fitzgerald, 2019; Miley, 2018; Wall, 2019).

\section{Votes of no confidence and a resignation}

In late February Sinn Féin tabled a motion of no confidence in Minister for Health Simon Harris. The motion was tabled in response to the controversy surrounding the increasing costs of constructing the National Children's Hospital and was defeated by fifty-eight to fiftythree votes. As per the terms of the confidence and supply agreement, Fianna Fáil abstained (see McConnell, 2019).

In early December the Social Democrats tabled a motion of no confidence in Minister for Housing, Planning and Local Government Eoghan Murphy, TD. With the country in the midst of an everworsening housing crisis, this was the second time in approximately 
fourteen months that Murphy had faced such a vote, with Sinn Féin tabling a vote of no confidence in the minister in late September 2018. The minister survived the vote by fifty-six to fifty-three votes; again, Fianna Fáil abstained. The result of the vote allowed for the survival of the government and averted a potential Christmas election (see O'Halloran, 2019).

On 4 December Fine Gael's Dara Murphy, TD, resigned his post in the Dáil in order to take a position in the European Commission. Murphy's resignation had been slightly delayed in order to allow him to cast a ballot in the vote of no confidence in party colleague Eoghan Murphy. Murphy's resignation sparked controversy as it emerged he had been claiming Dáil expenses despite taking up a job with the European People's Party in September 2017. His new appointment had severely impacted upon his Dáil attendance. Indeed, he had the lowest attendance of any TD in the Dáil for the period September 2017 to December 2019. Therefore, questions were raised over the legitimacy of the expenses Murphy had been claiming. Prior to his resignation Murphy stated that he would be happy to cooperate with an inquiry into his attendance and expenses. However, to date, Murphy has refused to cooperate with attempts to hold such an inquiry (see McConnell, 2019).

\section{Economic growth and budget 2020}

The Irish economy continued to perform strongly in 2019, with the Economic and Social Research Institute forecasting GDP growth at 5.8 per cent and unemployment expected to average 5 per cent in 2019 (Economic and Social Research Institute, 2019). This strong economic performance allowed for a positive budget by the Minister for Finance, Paschal Donohoe, TD, including $€ 3.1$ billion in additional spending. However, this large increase in spending had to be somewhat offset with tax increases on stamp duty and carbon taxes, amongst others (see Kelly et al., 2019).

\section{Other significant political events}

The first sitting of the Dáil in January was housed in the Mansion House in order to celebrate the centenary of the first sitting of the inaugural Dáil there in 1919 (see McConnell, 2019).

In January, following his resignation the previous November from Sinn Féin due to his personal views on abortion being at odds with the 
party whip, Peadar Tóibín founded a new political party named Aontú. The party ran fifty-three candidates in the local election, winning three seats (see Bray, 2019).

In February former Rehab CEO Angela Kerins won key elements of her Supreme Court appeal concerning her treatment before the Dáil Public Accounts Committee (PAC). In January 2017 Kerins had lost her High Court action that her rights had been breached during PAC meetings. The High Court ruled that utterances made in parliament were constitutionally protected and could not be adjudicated on by the court. However, the Supreme Court declared that the PAC had acted unlawfully in its treatment of Ms Kerins during hearings held in 2014. The High Court will make a decision on a later date as to whether Ms Kerins is entitled to any damages (see Carolan, 2019).

In April a report published by non-profit Reporters Without Borders ranked Ireland as sixteenth in the world for press freedom, a reduction from fourteenth in the previous report. The report criticised the print and broadcasting markets for being dominated by two players, Independent News and Media in the case of the newspaper market and semi-state RTÉ in the case of broadcasting. Further, the report noted that defamation suits were commonplace with large damages awarded in these cases, and that such an environment inhibits journalists' ability to do their job (see Hosford, 2019).

In June the President of the US, Donald Trump, made an official state visit to Ireland. During the short trip President Trump spent time in Co Clare, where he owns a hotel and golf course. While in Ireland President Trump compared Ireland's concerns over the impact that Brexit will have on the Northern Irish border with the 'border situation' in the US. However, in the same press conference Taoiseach Varadkar quickly pointed out that the situations were very different (see McConnell, 2019).

In September Noel Grealish, TD, a member of the Rural Independent Group, made controversial remarks at a direct provision centre public meeting in Oughterard, Co Galway. Grealish claimed that economic migrants from Africa were coming to 'sponge off the system'. Grealish was widely criticised for the remarks. Later in the year Grealish also courted controversy when speaking in the Dáil, where he sought assurances that remittances from Ireland to Nigeria were not the proceeds of crime (see McQuinn, 2019).

In October Fianna Fáil's Timmy Dooley, TD, and Niall Collins, $\mathrm{TD}$, were forced to step down from their positions on the party's front 
bench when footage emerged of Collins casting a vote in the Dáil on behalf of Dooley. Their Fianna Fáil colleague Lisa Chambers, TD, also cast two votes that day, initially sitting in the wrong seat. Further, Collins was also shown to have cast a vote in TD Barry Cowen's seat. It later emerged that this practice was widespread in the Dáil with prominent ministers, including Taoiseach Varadkar, admitting to voting on behalf of other people who were not in the chamber. The rules were subsequently tightened and now TDs must vote from their assigned seats. The Dáil Ethics Committee probed the controversy but none of the TDs faced suspension (see McConnell, 2019).

In November the government signed off on the controversial $€ 3$ billion National Broadband Plan (NBP). The plan attracted controversy for two reasons: firstly, costs spiralled, with the $€ 3$ billion finally agreed far in excess of what had been expected at the end of 2018; secondly, there was controversy surrounding the naming of the Graham McCourt consortium as the preferred bidder. Some critics felt that the bidding should have been reopened, with the contract awarded to someone else. For example, eir claims it can deliver the plan for a cost of $€ 1$ billion. Other critics contend that, given the large investment by the state, the new broadband network should remain in state ownership. In combination with the increasing costs of the National Children's Hospital, opposition TDs used the NBP as yet more evidence that Fine Gael could not competently manage the economy (see McConnell, 2019).

In late November, following her capture by Turkish forces in Syria, former Defence Forces member Lisa Smith was deported from Turkey to Ireland. Upon arrival in Dublin Airport she was charged with being a member of the terrorist organisation ISIS. Smith is currently on bail while she awaits trial (see Lally, 2020).

Throughout the year the government received constant criticism for the escalating homeless 'crisis', with the number of homeless people in the state increasing by 5 per cent from January to October, with figures in March reaching the 10,000 mark for the first time in the state's history. With rent prices continuing to increase (the second quarter of 2019 marked the thirteenth consecutive quarter of rent increases across the country), images of armed and masked Gardaí evicting tenants, and several protests throughout the year, the government was forced to regularly defend its record on housing, culminating in the vote of no confidence in Minister for Housing, Planning and Local Government Eoghan Murphy (see Focus Ireland, 2019). 
At the end of the year, a Red $\mathrm{C}$ poll had support for the political parties at 32 per cent for Fine Gael, 24 per cent for Fianna Fáil and 11 per cent for Sinn Féin. Independent candidates enjoyed a 13 per cent share, while the Greens and Labour had 7 and 4 per cent support, respectively. The Social Democrats were estimated at 2 per cent, while Aontú and Solidarity/People Before Profit were both estimated at 1 per cent (see the Sunday Business Post, 2019).

\section{References}

Bray, J. (2019, 28 January). Peadar Tóibín to name new political party 'Aontú'. The Irish Times.

Carolan, M. (2019, 27 February). Former Rehab head Angela Kerins wins key parts of appeal against PAC. The Irish Times.

Duggan, A. (2019). Irish presidential election 2018. Irish Political Studies, 34 (2), 202-314.

Economic and Social Research Institute. (2019). Quarterly economic commentary: Winter 2019. Retrieved from https://www.esri.ie/system/files/ publications/QEC2019WIN.pdf [19 December 2019].

Election results 2019: Analysis in maps and charts. (2019, 13 December). Retrieved from https://www.bbc.com/news/election-2019-50770798 [23 December 2019].

Emerson. N. (2019, 12 December). Why should the DUP not take advantage if it wins enough seats in the election? The Irish Times.

Fitzgerald, C. (2019, 2 May). Nurses and midwives vote to accept deal to end industrial dispute. Retrieved from https://www.thejournal.ie/nurses-strike11-4617128-May2019/ [23 December 2019].

Focus Ireland. (2019). Latest figures on homelessness in Ireland. Retrieved from https://www.focusireland.ie/resource-hub/latest-figures-homelessnessireland/ [12 December 2019].

Hosford, P. (2019, 25 April). Ireland has slipped down in press freedom rankings because of concentrated ownership and defamation costs. Retrieved from https:/www.thejournal.ie/press-freedom-ireland-slips-3977022-Apr2018/ [23 December 2019].

Johnson, S. (forthcoming). The 2019 European Parliament elections in Ireland. Irish Political Studies.

Keenan, L. (forthcoming). The 2019 local elections in the Republic of Ireland. Irish Political Studies.

Kelly, F. (2019a, 14 November). Maria Bailey deselected as Fine Gael candidate for Dún Laoghaire. The Irish Times.

Kelly, F. (2019b, 17 November). Fine Gael candidate apologises for comments on asylum seekers. The Irish Times.

Kelly, F., Taylor, C., \& Leahy, P. (2019, 7 October). Extra tax hikes included in Budget 2020 to fund $€ 3.1$ billion in spending. The Irish Times. 
Lally, C. (2020, 1 January). Lisa Smith signs on at Garda Station as part of bail conditions. The Irish Times.

Leahy, P. (2019, 21 December). Four political trends we will not be able to avoid in 2020. The Irish Times.

Leahy, P., McClements, F., \& Moriarty, G. (2019, 15 November). Smith warns of North elections if executive does not return by January 13th. The Irish Times.

Live results from by-elections. (2019, November 30). Retrieved from https://www.rte.ie/news/by-elections-2019/results/\#/cork-north-central [10 December 2019].

McClements, F. (2019, 18 August). Lyra McKee: 'Intensive' inquiry into journalist's murder continues. The Irish Times.

McConnell, D. (2019, 31 December). A political year in review: Politicians show they can still push people's buttons in Dáil's centenary year. The Irish Examiner.

McGee, H. (2019, 4 November). Byelections to fill vacant Dáil seats set for November 29th. The Irish Times.

McQuinn, C. (2019, 14 September). Pressure on Noel Grealish to withdraw claim Africans 'sponge off the system'. The Irish Independent.

Miley, I. (2018, 18 December). INMO votes for strike over pay and staff shortages. Retrieved from https://www.rte.ie/news/health/2018/1218/ 1017860-inmo/ [23 December 2019].

Moore, D. (2019). The blasphemy referendum 2018. Irish Political Studies, 34 (2), 315-25.

O’Donnell, H. (2017). Political developments, 2016. Administration, 65 (1), $1-8$.

O’Halloran, M. (2019, 3 December). Minister for Housing Eoghan Murphy survives vote of no confidence. The Irish Times.

Pollak, S. (2019a, 17 November). Oughterard withdrawal latest example of direct provision's flaws. The Irish Times.

Pollak, S. (2019b, 17 November). Rooskey locals express relief at decision to scrap direct provision plan. The Irish Times.

Quinlivan, A. (forthcoming). The 2019 local elections in the Republic of Ireland. Irish Political Studies.

Red C. (2019, October). Red C/The Sunday Business Post general election opinion poll. Retrieved from https://www.redcresearch.ie/ wp-content/uploads/2019/10/SBP-October-2019-Poll-Report.pdf. [15 December 2019].

Wall, M. (2019, 29 March). Dispute over nurses' pay and conditions not settled, says INMO. The Irish Times. 